\title{
From Marketing Mix to E-Marketing Mix: a Literature Overview and Classification
}

\author{
Gandolfo Dominici (PhD) \\ Assistant professor of Marketing and Management \\ Dep. S.E.A.F, Faculty of Economics, University of Palermo \\ Viale delle Scienze (Parco D'Orleans), ed. 13 \\ 90128 Palermo, Italy \\ Tel: 39-091- 6626-269, Fax: 39-091-489-346 E-mail: gandolfodominici@unipa.it
}

\begin{abstract}
The marketing mix paradigm, in its famous version of the 4 Ps, went all the way through the evolution of marketing theory being object of discussion both in academic literature and managerial practice. Though it's a fact that the 4 Ps marketing mix is a milestone of marketing theory, it is also true that the evolution of business contexts has created the need to review the "controllable factors" which form the marketing mix. The digital business represents the more recent of the business contexts and the one with the greater need for a differentiation of the mix. Throughout this evolutionary process, researchers have always been divided between the "conservatives", who think the 4 Ps paradigm is able to adapt to the environmental changes by including new elements inside each "P", and the "revisionists", who affirm that the 4 Ps paradigm is obsolete and propose new paradigms. This paper aims to clarify these two different approaches to marketing mix evolution through a review of the main literature regarding e-marketing mix, focusing on the development of marketing mix theory for the digital context.
\end{abstract}

Keywords: E-marketing, Marketing mix, E-marketing mix

\section{Introduction}

The business environment faced many changes since when, in 1953, Neil Borden for the first time introduced the term "marketing mix" in his speech at the American Marketing Association, and since Jerome McCarthy (1964) defined the 4 Ps marketing mix as a combination of all the factors which managers may leverage to satisfy market needs. Comprehending the roots of the traditional marketing mix is crucial in order to understand the distinction between "conservatives" and "revisionists" proposed in this paper.

\subsection{Theoretical framework}

In McCarthy's version, the marketing mix is composed of: product, price, place and promotion. Each of these Ps comprise a number of the twelve managerial policies described by Borden (1964), thus including other sub-mixes within each P. As noted by Kalyanam \& McIntyre (2002), the marketing mix is a collection of thousands of micro-elements clustered together in order to simplify managerial activity. The validity or the exclusion of the traditional mix in the digital context is a matter of if and how it is possible and convenient to extend the number of elements it includes or to dismiss it and create a new one (Figure 1).

In the formulation of his twelve elements Borden (1964) pointed out that it is necessary to create: «1) a list of the important elements or ingredients that make up marketing programs; 2) a list of the forces that bear on the marketing operation of a firm and to which the marketing manager must adjust in his search for a mix or program that can be successful».

McCarthy's marketing mix has been widely adopted through time by managers and academics, becoming a key element of marketing theory and practice. This wide diffusion may be justified on the basis of its simplicity of use and understanding which makes it a useful tool both for marketing decisions and teaching. (Grönroos, 1994; Yudelson, 1999; Jobber, 2001). The concept of marketing mix is considered in the Managerial School of Marketing (MSM) (Sheth 
et al., 1988) as an operative tool to achieve marketing objectives, in particular as a formula for those marketing factors that can be controlled by the enterprise in an uncontrollable competitive environment (Varaldo, 1996).

As the MSM evolved through various stages in time, from the marketing concept of the 1970's, through the introduction of Total Quality Management in the 1980's (Yudelson, 1999), and relationship marketing in the 1990's, to today's adaptation to the digital context, the marketing mix has always been matter of discussion, both between managers and academics.

There is no doubt that the changes in the social and economic environment, and the consequent transformation of the competitive arena, have a strong impact on the marketing mix. The digital context, in particular, is where the original version of marketing mix shows major limitations.

The interaction with the customer and the communication capabilities of Internet were unimaginable in the 1960's. The 4 Ps were created for a manufacturer context. Nevertheless the adaptive capability of the 4Ps allow their application in competitive contexts that are significantly different from those for which they were created. The question which this paper aims to underscore is: "Is it possible to create a new list of elements that can adequately modify the traditional mix to fit in new digital contexts?".

There are two different approaches among researchers regards the way to change the traditional marketing mix. Part of the researchers (which we call "conservatives") assert that the 4 Ps may continue to be the dominant paradigm of marketing mix in digital contexts, since it is sufficient to change the sub-mixes within each $\mathrm{P}$ adding and/or deleting some factors in order to adapt to the new scenario. Other authors (which we call them "revisionists") suggest that the 4 Ps' framework is now obsolete and propose to add other elements and /or to change the elements of the mix. Both approaches give significant motivations to support their conclusions. This paper aims to clarify these motivations through a review of the main literature on the subject.

\subsection{Objective and delimitation of research}

This study delivers a literature overview and classification in order to give a picture of the current standing of the debate about the convenience of adopting the traditional marketing mix in digital environments. The paper doesn't want to give an answer to this question, but to highlight some relevant aspect to be considered in the debate.

The most important limitation of this work is that it reviews only academic opinions published in research papers and academic textbooks, with no consideration of field experience. The paper underlines the need for further research on the issue.

\section{New marketing mix for the digital business environment: the revisionists' view}

There is a wide range of studies and research which stems from the need to find a new paradigm for operative marketing which, surpassing the 4 Ps, can define more specifically the marketing levers. This stream of research, which we call "revisionist", asserts the need for a radical reconceptualization. The main argument against the 4 Ps is that the model is internally oriented; this limitation leads to the lack of customer orientation and the insufficient attention to the relationship with customers (Möller, 2006; Popovic, 2006, Constantinides, 2002 a, b). Schultz (2001) points out that in today's marketplaces there is the need for a new externally oriented paradigm which considers the network system view. A common factor in all the "revisionist" e-marketing mix literature examined is the perception of the need for a more explicit customer orientation. This limitation includes all the aspects of today's marketing, nevertheless it has a particularly strong repercussion in Internet marketing, where interactivity is regarded as a crucial aspect.

It is interesting to notice that, in spite of these criticisms, the majority of the "revisionists" authors reviewed agree to include the 4 Ps in their marketing mix models, with few exceptions.

Lawrence et al. (2000) propose to add to the traditional 4 Ps' mix other two Ps, which have been debated in the marketing mix literature since several decades: people and packaging; this mix is then included in a 5 Ps marketing concept: paradox, perspective, paradigm, persuasion and passion. In the Italian literature, Prandelli and Verona (2006) propose a 3 Cs model, where each C contains some key elements: content (Web site and platform), community (interaction platform and relational capability), commerce (including the 4 Ps: product, price, place and promotion); while Pastore and Vernuccio suggest a $3 \mathrm{C}+\mathrm{I}$ (interface) model where the $4 \mathrm{Ps}$ are integrated and recontextualized in the on-line environment as described in figure 2.

Kalyanam \& McIntyre (2002) include the $4 \mathrm{Ps}$ inside their $4 \mathrm{P}+\mathrm{P}^{2}+\mathrm{C}^{2}+\mathrm{S}^{3}$ model in a wider operative context which, thanks to the three-dimensional representation, can give a more complete taxonomy of the elements forming the mix, as represented in figure 3.

Chen (2006) highlights the importance accorded to the environment and interaction in the model proposed by the Chinese researchers of National Taiwan University (1999), which considers 8 Ps, four of which are the traditional Ps (figure 4). 
In the 8 Ps' model:

- Precision refers to the increased accuracy of the selection process of the target segment and to market positioning in digital contexts, thanks principally to database management systems;

- Payment systems must be secure and easy for customers to use;

- Personalization concerns the possibility to create a flexible interface, which is able to adapt to customers' needs and wills;

- Push and Pull regards the choice of trade-off among active communication policies (push) and communication on users' demand (pull).

While these models include the traditional 4 Ps as their core elements, other authors propose entirely different mixes. Chaffey et al. (2000) assert that the Internet calls for a change of the traditional marketing mix and spot eight critical issues to be considered in marketing planning at the strategic level: audience, integration, marketing support, brand migration, strategic partnership, organization structure and budget. Also the Web Marketing Mix Model of Constantinides (2002a) extends the mix to strategic and business organization levels and suggests a $4 \mathrm{~S}$ model including the following elements:

- Scope, of strategic relevance includes: strategic objectives, market analysis and potential, stage of e-commerce maturity, strategic role of e-commerce for the organization;

- Site, has operational value and involves interface issues;

- Synergy, has organizational significance including the integration among bricks and clicks aspects of the company's business model;

- System, concerns the management of the Web platform, the data warehouse and the security systems.

\section{Maintaining the 4 Ps in digital contexts: the conservatives' view}

While it is not possible to ignore the need to adjust the marketing mix to the changes in the society and the market produced by the diffusion of digital technologies, Internet in particular, a less numerous, but theoretically consistent, part of the literature on the topic asserts that the 4 Ps' model is perfectly able to adapt and to continue to be the dominant paradigm in these new contexts (Aldridge et al., 1997; Peattie, 1997; O'Connor \& Galvin, 1997; Bhatt \& Emdad, 2001; Allen \& Fjermestad, 2001; Möller, 2006).

Möller (2006) points out how the "internal orientation" criticism regards the 4 Ps is based on a misconception of the relation between the marketing mix and the marketing concept. For Möller the 4 Ps paradigm is perfectly coherent with the marketing concept which states that "marketing activities should be based on identification of customer needs and wants", also implying the selection of the explicit information to be gathered from the customers in order to be able to fulfil their needs, through segmentation, product differentiation and positioning.

Peattie (1997) pointed out how the new communicative capabilities supplied by the digital technologies are radically changing marketing in several sectors, but the marketing mix approach is able to adapt to the new needs: product, with the introduction of co-design with customers; price, with higher levels of transparency; place, with the creation of new ways to reach customers; and promotion, thanks to the new interactive capabilities. Bhatt \& Emdad (2001) see the empowerment of the 4 Ps since the virtual value chain is internally transforming each $\mathrm{P}$ by adding new dimensions: personalized information in the Product, transparency and personalization of Price, direct delivery for Place, improved flexibility for Promotion. O'Connor \& Galvin (1997), while assuming that the traditional marketing mix paradigm needs to evolve, propose that digital technologies can be useful to improve the mix's functionality maintaining the 4 Ps as the basic instrument for Internet marketing.

Among the changes brought to each of the 4 Ps by the digital technologies, the following are the most relevant:

- Product. The product should nowadays be redefined as: all the benefits through time that the user obtains from the exchange (Yudelson, 1999); this definition applies to the digital context. From the supply side, product policies can gain great benefits from the capability of Internet to engage the consumer in long term relationships that lead to the development of new products. The interactive and connective potential of Internet leads to a new product concept: the "virtual product" (Valdani, 2000; Pastore \& Vernuccio, 2004). The virtual product is seen as the union of tangible and intangible aspects, which is adapted and personalized according to the variety and variability of individuals' preferences by customizing the product with the active help of consumers (von Hippel, 2005; Dominici, 2008b). A product can be delivered from producer to consumer in digital form (mp3 for music, avi for movies, pdf for books and magazines, and so on) thus contextualizing their fruition in the digital framework (Pastore \& Vagnani, 2000). From the demand side, the capability of retrieving information plays a key role (Smith \& Chaffey, 2001). Andreini (2006) underlines the effectiveness of Nelson's classification (1970) which divides products in two categories: "search", when it is possible to obtain complete information before the purchase and "experience", when it is not possible, or too expensive, to gather 
information before the use of the product. Internet has been of great help for the purchasing process of "search" products, thanks to the easiness and affordability of retrieving information online, that, together with the increasing quantity of information and the interactivity of Web 2.0, has made it also possible to transform experience products into search products (Klein, 1998; Andreini, 2006).

- Price. The price should be redefined as everything given by the acquirer in terms of money, time and effort given to obtain the product (Yudelson, 1999). From the consumer's perspective, the main benefits of the Web concern the reduction of information asymmetries that allow the consumer to compare prices in real time and gain more transparency (Bhatt \& Emdad, 2001). Moreover, the implementation of Artificial Intelligent Agents enable to make automatic and tailored comparisons of prices and features, reducing the price in terms of time and effort (Dominici, 2008a). From the producer's point of view, Internet makes it possible to modify prices in real time; this could lead to dangerous price competitions (Allen \& Fjermestad, 2001) with the consequent reduction of profit margins. To avoid this, online communication must be directed towards qualitative aspects and differentiation attributes of the product.

- Place. Can be defined today as: everything that is done and necessary to smooth the process of exchange (Yudelson 1999). The application of this definition to the digital context urges to add the element of purchasing process as a key feature of place within the mix. The process must be smooth and easy, while building relations with customers at the same time. The physical place becomes virtual and includes intangible aspects of transaction. Bhatt \& Emdad (2001) underline that the main contribution of Internet to business is not the mere possibility of selling products online, rather its capability of building relations with customers. The interactive capabilities of Internet allow the implementation of more efficient and effective systems of digital Customer Relationship Management (e-CRM). Internet enables to obtain information which can be used to manage customers, thanks to the data gathered through the registration of users to the company's Web page and the online purchase data for each customer. This helps to maintain the service level and improve the management of the customer portfolio (Fjermestad \& Romano, 2003; O'Learly et al., 2004).

- Promotion. Can be redefined in order to include: all of the information that is transmitted among parties (Yudelson, 1999). This definition includes also the interactive aspects of digital communication. The Internet is different from other mass communication media (Morris \& Ogan, 1996). Infact, while it is surely a medium which can reach a numerous and dispersed audience, it differentiates itself from the other media regards interactive and multimedia features. Hoffman \& Novak (1997) point out that, in the Web environment, the one-to-many concept loses its cogency, while the new many-to-many paradigm takes its place. Personal interaction allows to issue messages directed to a specific individual with a degree of flexibility which no other media can be capable of (Bhatt \& Emdad). This also makes it possible to hit the target while he/she is in a situation of relax and confidence (defined as "low involvement" by Krugman, 1965) similar to that of television, but with higher informative capability, due to the multimedia features of the Web communication. The aim of online communication is not just to advertise a product, but to built a purchase relation and create a perception of trust in the customer. Interaction, multimedia and relationship should be included as elements of the $\mathrm{P}$ of promotion.

\section{Conclusions and further research}

The 4 Ps marketing mix was created in the early days of the marketing concept when physical products, physical distribution and mass communication were dominant. Today, with the new business environment created by the different and empowered capabilities of digital contexts, the marketing mix paradigm increasingly becomes object of criticisms. Although the mix has the capacity to include a wide set of variables in order to adapt to a large range of mutations in the business environment, many authors believe it is obsolete and inadequate for the $21^{\text {st }}$ Century. The search for a new dominant paradigm for operative decisions in digital environments is still in progress. We are still far from finding a new widely accepted standard able to fully substitute the 4 Ps' mix after almost half century. The reason underlying this lack of a new universally accepted model is probably the imperfect comprehension of the full potential of the new digital technologies for business and the insufficient emphasis given to case study research on marketing operations. On-line companies have still to reach their full maturity, which industrial enterprises had reached when McCarthy formulated the 4 Ps. Until now, after almost fifty years, it is apparent that, despite the controversies between "conservatives" and "revisionists", the basic construction of 4 Ps is still valid and, with some extension and adjustment, is still the core of operative decisions.

The conservatives' view described is based on the possibility to change the elements inside each P of the traditional mix. As Borden (1964) formulated twelve elements through evidence emerging from empirical practices and case histories in the 1960's, there is a need for research on this topic also today.

When e-marketing research and practice will arrive to a deeper comprehension and maturity in the digital environment, we will probably see a new marketing mix paradigm which will definitely put to the traditional 4 Ps to rest and give light to a new widely accepted paradigm for marketing operations. 


\section{References}

Andreini D. (2006). The Evolution of the Theory and Practice of Marketing in Light of Information Technology, in Krishnamurthy S. Contemporary Research in E-Marketing, Vol. 2, pp. 168-215.

Borden N.H. (1964). The Concept of the Marketing Mix. Journal of Advertising Research, 24 (4): 7-12.

Bruner G. C. (1988). The marketing mix: A retrospective and evaluation. Journal of Marketing Education, 10: 29-33.

Chaffey D., Mayer R., Johnston K., Ellis-Chadwick F. (2000). Internet Marketing, Strategy, Implementation and Practice, FT/Prentice Hall.

Chen C-Y. (2006). The comparison of structure differences between internet marketing and traditional marketing. International Journal of Management and Enterprise Development, 3 (4): 397-417.

Constantinides E. (2006). The Marketing Mix Revisited: Towards the 21st Century Marketing. Journal of Marketing Management, 22 (3): 407-438.

Constantinides E. (2002a). The 4S Web-Marketing Mix model. Electronic Commerce Research and Applications, 1: 57-76.

Constantinides E. (2002b). From Physical Marketing to Web Marketing: The Web-Marketing Mix. atti della $35^{t^{\text {th }}}$ Hawaii International Conference on System Sciences.

Culliton J. W. (1948). The Management of Marketing Costs, Boston: Division of Research. Graduate School of Business Administration, Harvard University.

Dixon D. F., Blois K. J. (1983). Some Limitations of the 4 Ps as a Paradigm of Marketing, in Blois K. J. (a cura di). Proceedings of the Marketing Education Group, pp. 92-107.

Dominici G. (2008a). Holonic Production System to Obtain Flexibility for Customer Satisfaction. Journal of Service Science and Management, 1 (3): 251-254.

Dominici G. (2008b). Demand Driven Supply Chain ed innovazione: il sistema logistico-produttivo per la soddisfazione dei bisogni del cliente in Purpura A. \& Fazio G. (ed.), Economia e gestione dell'innovazione nelle PMI. Percorsi tematici ed esperienze formative del Master EGI, pp. 100-114, FrancoAngeli.

Dominici G. (2009). E-marketing cosa cambia? Dai modelli di business al mix operativo, Milan: FrancoAngeli.

E-center of National Taiwan University of Science and Technology. (1999). The Electronic Commerce, TsangHai Book Co., pp.2-150.

Fjermestad J., \& Romano N. C. J. (2003). An Integrative Implementation Framework for Electronic Customer Relationship Management: Revisiting the General Principles of Usability and Resistance, proceedings of the $36^{\text {th }}$ Hawaii International Conference on Systems Sciences.

Goi C.L. (2005). Marketing Mix: a Review of 'Ps'. Journal of Internet Banking and Commerce, 10 (2). [Online] Available: www.arraydev.com/commerce/JIBC/2005-08/goi.htm

Goi C. L. (2009). A review of Marketing Mix: 4Ps or More? International Journal of Marketing Studies, 1 (1): 2-14.

Goldsmith R. E. (1999). The Personalized Marketplace: Beyond the 4Ps. Marketing Intelligence \& Planning, 17 (4): 178-185.

Goldsmith R. E. (2002). Explaining and Predicting Consumer Intention to Purchase over the Internet: An Exploratory Study. Journal of Marketing Theory and Practice, 10 (2): 22-28.

Grönroos C. (1994). Quo vadis marketing? Toward a relationship marketing paradigm. Journal of Marketing Management, 10 (5): 347-360.

Grönroos C. (1994b). From Marketing Mix to Relationship Marketing: Towards a Paradigm Shift in Marketing. Asia-Australia Marketing Journal, 2 (1): 9-30.

Grönroos C. (2000). Relationship Marketing: The Nordic School Perspective”, in Sheth J. N., Parvatiyar A. (a cura di), Handbook of Relationship Marketing, Sage.

Grönroos C. (2005). On defining marketing: finding a new roadmap for marketing. Marketing Theory, 6 (4): 395-417.

Grönroos C. (2008). In Search of a New Logic for Marketing: Foundations of Contemporary Theory, Wiley.

Hoffman, D.L., \& Novak, T.P. (1997). A New Marketing Paradigm for Electronic Commerce. The Information Society: An International Journal, 13: 43-54.

Jobber D. (2001). Principles and Pactices of Marketing $3^{\text {rd }}$ edition, McGraw Hill. 
Kalyanam K., \& McIntyre S. (2002). The E-marketing Mix: a Contribution of the E-Tailing Wars. Academy of Marketing Science Journal, 30 (4): 487-499.

Klein L. R. (1998). Evaluating the potential of interactive media through a new lens: Search versus experience goods. Journal of Business Research, 41: 195-203.

Lambin J. J. (1972). A Computer On-Line Marketing Mix Model. Journal of Marketing Research, 9: 119-126.

Lasswell H. D. (1948). The Structure and Function of Communication in Society, in Bryson L. (a cura di), The Communication of Ideas, Harper \& Bro.

Lawrence E., Corbitt B., Fisher J. A., Lawrence J., \& Tidwell A. (2000). Internet Commerce: Digital Models for Business ( $2^{\text {nd }}$ ed.), Wiley \& Sons.

Lauterborn R. (1990). New Marketing Litany: 4Ps Passes; C-Words Take Over, Advertising Age, ottobre, pp.26-28.

McCharty E.J. (1960). Basic Marketing: A Managerial Approach, Irwin.

McCharty E.J. (1964). Basic Marketing: A Managerial Approach, $2^{\text {nd }}$ ed., Irwin.

McCarthy E. J., \& Perreault W.D. Jr. (1987). Basic Marketing: A Global Managerial Approach, Irwin.

Möller K. E. (1994). Interorganizational Marketing Exchange: Metatheoretical Analysis of Current Research Approaches, in Laurent G. Lilien G, Pras B. (a cura di), Research Traditions in Marketing, pp. 348-382, Kluwer.

Möller K. E., \& Halinen A. (2000). Relationship Marketing Theory: Its roots and directions. Journal of Marketing Management, 16 (1): 29-54.

Möller K. E. (2006). Comment on: The Marketing Mix Revisited: Towards the $21^{\text {st }}$ Century Marketing? by E. Constantinides. Journal of Marketing Management, 22 (3): 439-450.

Morris M., \& Ogan C. (1996). The Internet as Mass Medium. Journal of Computer Mediated Communication, 1 (4), [Online] Available: http://jcmc.indiana.edu/voll/issue4/morris. html

Mosley-Matchett J. D. (1997). Include the Internet in marketing mix. Marketing News, 31 (25).

Nelson P. (1974). Advertising Information. Journal of Political Economy, 83: 729-754.

O’Learly C., Rao S., \& Perry, C. (2004). Improving Customer Relationship Management through Database/Internet Marketing. A Theory-building Action Research Project. European Journal of Marketing, 38 (3/4): 238-254.

Pastore A., \& Vagnani G. (2000). Il ruolo dell'e-commerce nell'evoluzione dei sistemi distributivi. Industria $e$ Distribuzione, 1: 33-46.

Pastore A., \& Vernuccio M. (2004). Marketing, Innovazione e Tecnologie Digitali. Una lettura in ottica sistemica, Padua (IT): Cedam.

Pastore A., \& Vernuccio M. (2008). Impresa e comunicazione. Principi e strumenti per il management. $2^{a}$ ed.., Milan: Apogeo.

Popovic D. (2006). Modelling the marketing of high-tech start-ups. Journal of Targeting, Measurement and Analysis for Marketing, 14 (3): 260-276.

Prandelli E., \& Verona G. (2006). Marketing in Rete, Milan: McGraw-Hill.

Robins F. (2000). The E-marketing mix. The Marketing Review, 1: 249-274.

Schultz D. E. (2001). Marketers: Bid Farewell to Strategy Based on Old 4Ps. Marketing News, 35 (2): 7.

Vignali C., \& Bavies B. J. (1994). The Marketing Mix Redefined and Mapped: Introducing the MIXMAP Model. Management Decision, 32 (8): 11-16.

Von Hippel E. (2005). Democratizing innovation, MIT Press.

Wang K.L., Wang Y., \& Yao J.T. (2005). A Comparative Study on Marketing Mix Models for Digital Products. Internet and Network Economics Proceedings of First International Workshop, WINE 2005, Hong Kong, China, 15-17 december, pp.660-669, Springer.

Yudelson J. (1999). Adapting McCarthy's Four P's for the Twenty-First Century. Journal of Marketing Education, 21 (1): 60-67. 


\begin{tabular}{|l|l|}
\hline Product & Place \\
Product Planning & Channels of Distribution \\
Branding & Display \\
Packaging & Physical Handling \\
Servicing & Fact Finding and Analysis \\
\hline Price & Promotion \\
Pricing & Personal Selling \\
& Advertising \\
& Promotions \\
\hline
\end{tabular}

Figure 1. McCarthy' 4Ps and the 12 policies of Borden

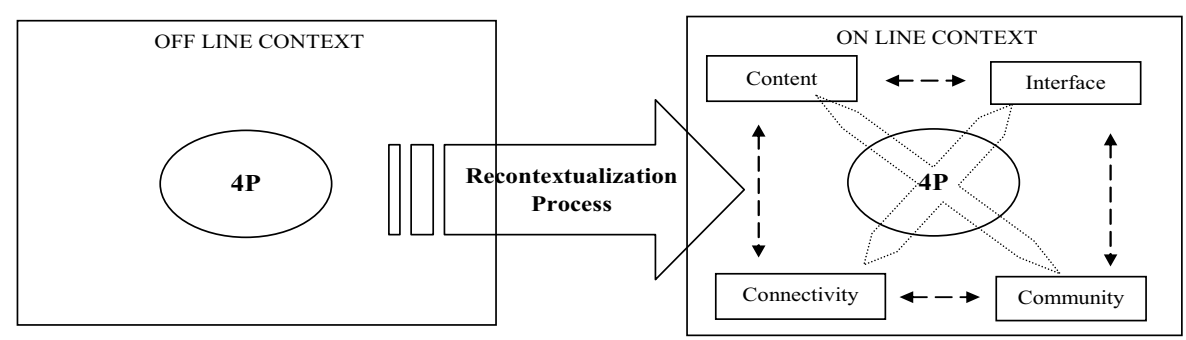

Source: Pastore \& Vernuccio, 2004

Figure 2. Contextualization of the $4 \mathrm{Ps}$ in the $3 \mathrm{Cs}+\mathrm{I}$

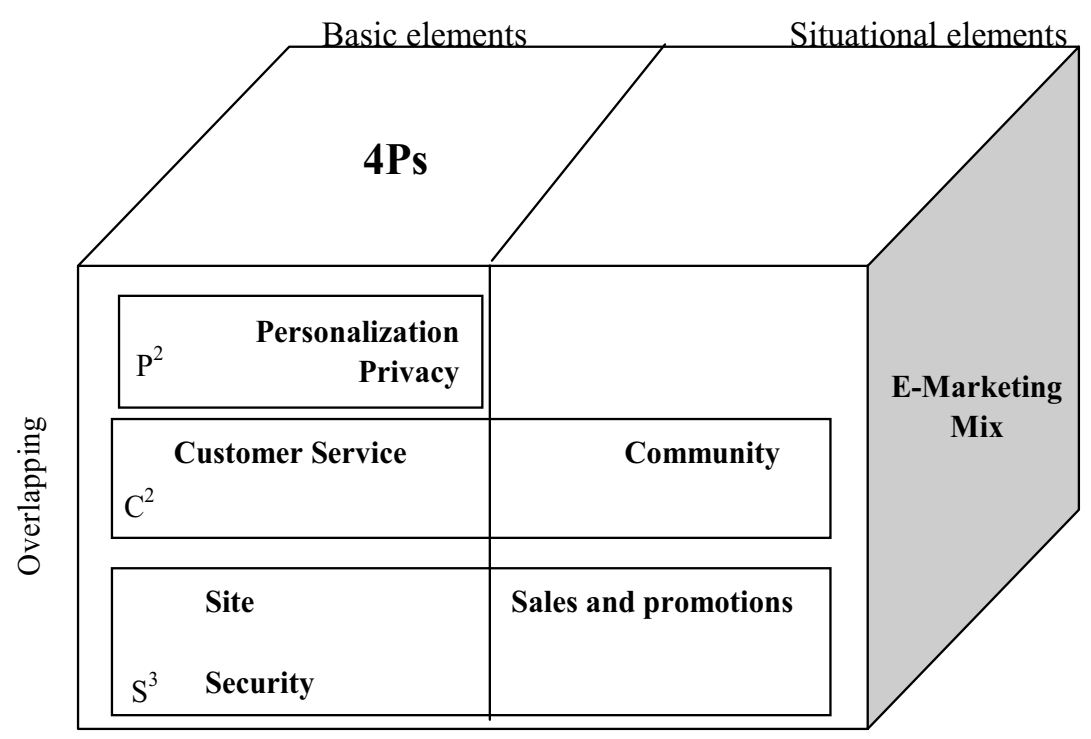

Source: Kalyanam \& McIntyre, 2002, p.496

Figure 3. The $4 \mathrm{P}+\mathrm{P} 2+\mathrm{C} 2+\mathrm{S} 3$ model 


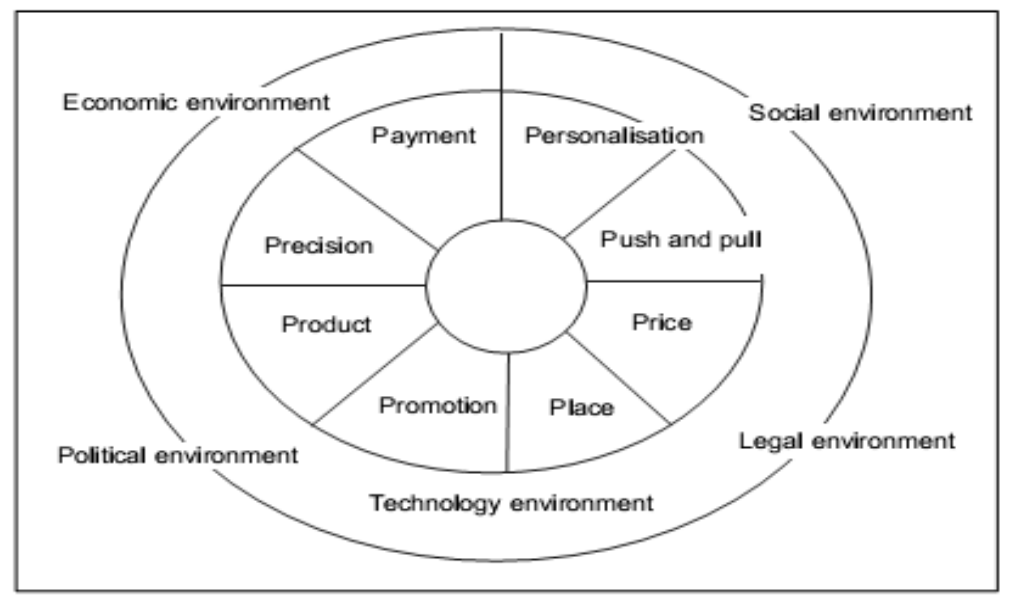

Figure 4. The 8Ps' Internet marketing mix model

Source: Chen, 2006, pp. 410. 